\title{
Brenner tumor of ovary: an incidental finding: a case report
}

\section{Bhanwar Singh Jodha, Richa Garg*}

Department of Obstetrics and Gynecology, Umaid Hospital, Regional Institute of Maternal and Child Health, Dr. S. N. Medical College, Jodhpur, Rajasthan, India

Received: 20 December 2016

Accepted: 31 January 2017

\author{
*Correspondence: \\ Dr. Richa Garg, \\ E-mail: richagarg1989@gmail.com
}

Copyright: (C) the author(s), publisher and licensee Medip Academy. This is an open-access article distributed under the terms of the Creative Commons Attribution Non-Commercial License, which permits unrestricted non-commercial use, distribution, and reproduction in any medium, provided the original work is properly cited.

\section{ABSTRACT}

Brenner tumor of the ovary is very rare, mostly benign, small, and unilateral. Malignant brenner tumor is much rarer. Malignant brenner tumor of ovary closely resembles the transitional cell carcinoma of ovary. These tumors are believed to arise from urothelial metaplasia of ovarian surface epithelium. However the latter has a worse prognosis. Here we present a case of Brenner tumor of ovary in a postmenopausal woman treated surgically and its features are briefly discussed.

Keywords: Brenner tumor, Ovarian neoplasm, Ultrasonography

\section{INTRODUCTION}

Ovarian tumors are common forms of neoplasia in women and it accounts for about $30.0 \%$ of female genital cancers. ${ }^{1}$ Ovarian carcinoma is the fourth most common female cancer and the fourth leading cause of death among cancer deaths in female. ${ }^{2-4}$ These tumors behave in diverse ways and usually they are detected after attaining a larger size. The ovarian lesion constitutes the major burden in gynecology practices due to anatomical location of the tumor and also due to the fact that these tumors may remain asymptomatic for a longer period of time. Transitional cell tumors of the ovary, described for the first time by Brenner in 1907, are rare neoplasms and account for about $2 \%$ of all ovarian tumors are common forms of neoplasia in women. Brenner tumor of the ovary is a relatively uncommon neoplasm. The average age at presentation is 50 years with $71 \%$ of the patients being more than 40 years. ${ }^{5}$ It constitutes $1.4-2.5 \%$ of all ovarian tumors and has a predilection for the postmenopausal woman. According to WHO, depending on the histopathological pattern, they are classified as benign, borderline or malignant Brenner tumors, and transitional cell carcinomas. ${ }^{6}$ Brenner tumor is a fibroepithelial tumor composed of transitional epithelial cell nests, similar to bladder epithelium. ${ }^{7}$ The Brenner tumors are usually small, solid, firm grayish knots up to $2 \mathrm{~cm}$ in size, however, they may also be quite big, and in such cases they usually have cystic components as a result of cystic degeneration and necrosis. They are mostly benign and $95 \%$ of cases are unilateral. Malignant cases are extremely rare (roughly about $2 \%$ of all cases), and less than $5 \%$ are proliferating or borderline. ${ }^{7}$

\section{CASE REPORT}

A 52-year-old postmenopusal multiparous woman presented umaid hospital with a history of mild pain abdomen since 1 month. At the time of examination her vitals were stable, and no abnormality was detected in general and systemic examination. A palpable mobile lump of $7 \times 5 \mathrm{~cm}$ size was found at the right side of pelvic region. On per speculum examination, vaginal wall and cervix were found to be normal. On per vaginal examination, uterus was normal in size, and a mobile lump $7 \times 5 \mathrm{~cm}$ size was found posterior to the uterus. The USG finding showed a $9.8 \times 8.6 \times 9.8 \mathrm{~cm}$ well-defined septated right adenaxal mass suggestive of ovarian tumor. MRI showed multiloculated benign appearing bilateral cystic intrapelvic masses, located posterior to the uterus 
right side $7.1 \times 5.4 \mathrm{~cm}$ and left side $5.2 \times 3.6 \mathrm{~cm}$. CA125 was $06.40 \mathrm{U} / \mathrm{ml}$. The patient was prepared for laparotomy. On laparotomy, a multilobulated solid ovarian tumor was found on left side (Figure 1).

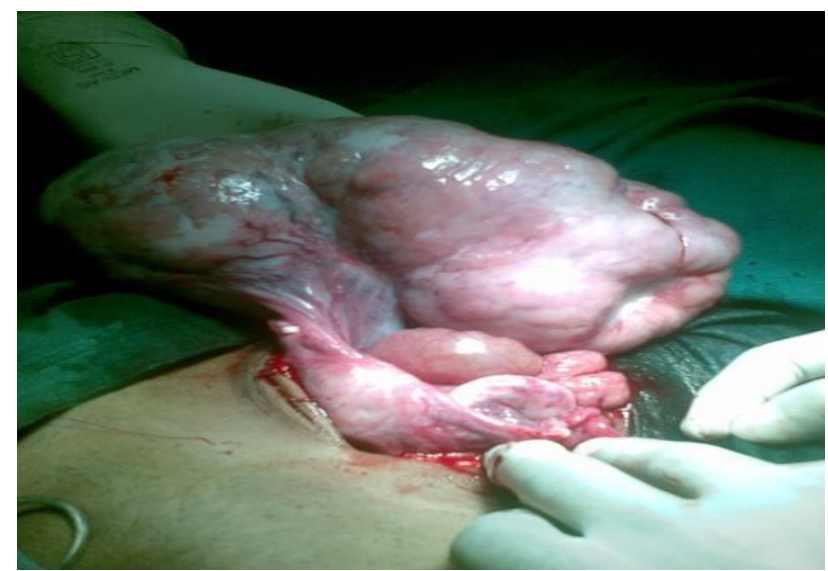

Figure 1: On laparotomy, a multilobulated solid ovarian tumor found on left side.

Total abdominal hysterectomy with bilateral salpingooophorectomy was performed with proper hemostasis. Grossly the right ovarian cyst was $6 \times 4 \times 3 \mathrm{~cm}$ sizes with serous fluid. Left ovarian cyst was $9.5 \times 5 \times 5 \mathrm{~cm}$. Cut surface showed nodules $1.5 \mathrm{~cm}$ in diameter. On histopathological examination myometrium showed adenomyosis and leiomyoma, well-circumscribed epithelial cell nests were found in left ovary with sharply demarcated borders, which are surrounded by abundant fibromatous stroma (Figure 4). Capsule not infilterated by tumour. The epithelial cells were ovoid to polygonal and had pale cytoplasm and oval nuclei. Some of the nuclei had central longitudinal groove (coffee bean appearance). All the above features go in favour of benign Brenner tumor of left ovary.one ovarian cyst shows adenofibroma other shows simple serous cystadenoma. Right ovary shows follicular cyst and cystic follicle. No evidence of malignancy. The postoperative period was uneventful and the patient was discharged with advice of regular followup.

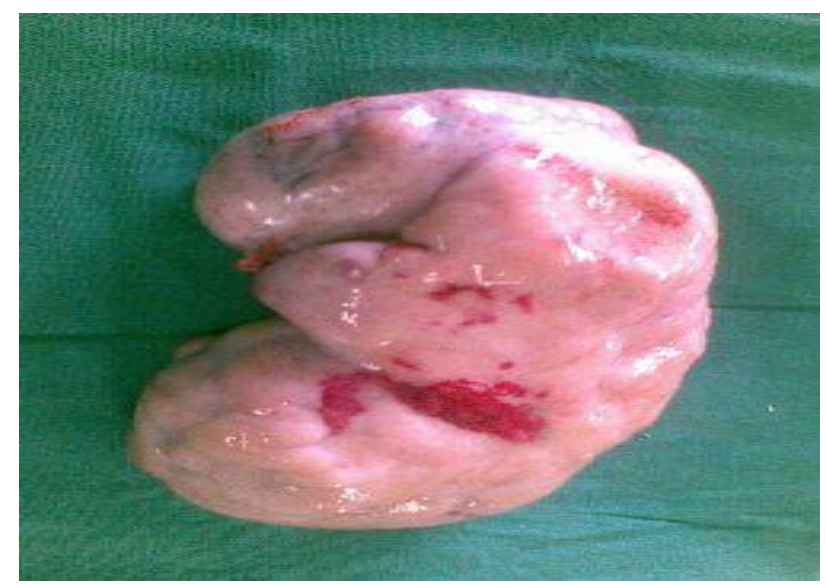

Figure 2: Gross specimen.

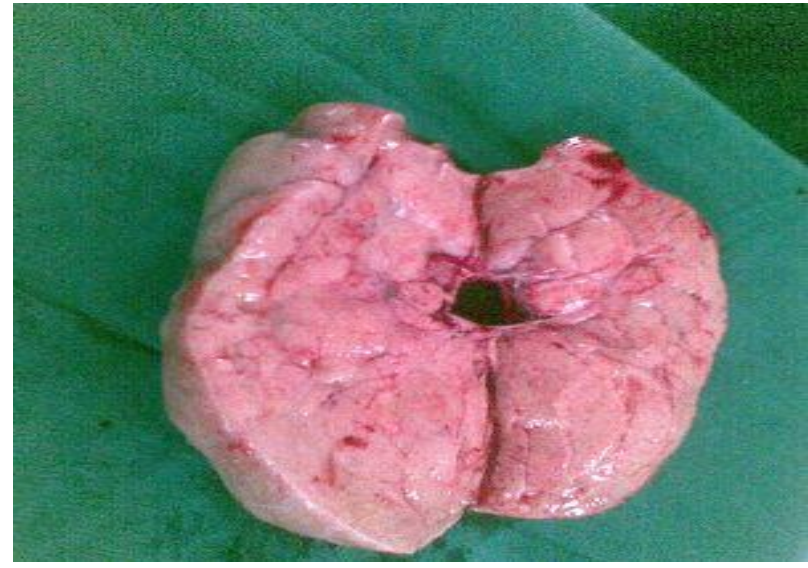

Figure 3: Cut section of the left-sided Brenner tumor.

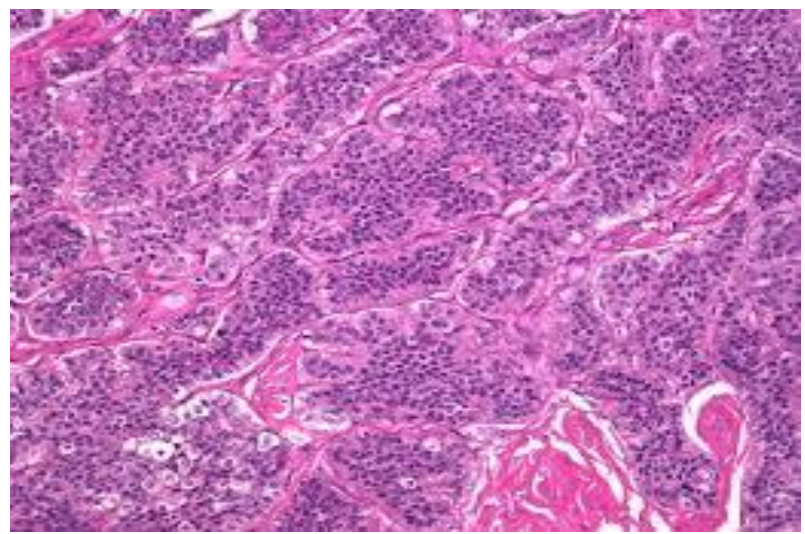

Figure 4: Microscopy showing epithelial cell nests separated by fibromatous stroma.

\section{DISCUSSION}

Brenner tumors are an uncommon subtype of the surface epithelial-stromal tumor group of ovarian neoplasms. The majority are benign, but some can be malignant. ${ }^{8}$

Brenner tumors were originally known as transitional cell tumors because of their histologic similarity to the urothelium. They are found incidentally on pathologic examination for oophorectomy performed for other reasons. Common symptoms include vaginal bleeding, a palpable pelvic mass, and pelvic pain. ${ }^{9}$

At pathologic examination, Brenner tumors are composed of epithelial nests surrounded by proliferating dense stromal tissue. The fibrous component is less prominent in borderline or malignant tumors than in benign lesions. Benign tumors are generally solid at pathologic examination. Size also correlates with histologic grade: most benign tumors are smaller than $5 \mathrm{~cm}$, and those with borderline or malignant histologic findings are larger than $5 \mathrm{~cm}$ at diagnosis. Brenner tumor in our case was benign.

They are most frequently found incidentally on pelvic examination or at laparotomy. ${ }^{10}$ Brenner tumours very rarely can occur in other locations, including the testis. ${ }^{11}$ 
On gross pathological examination, they are solid, sharply circumscribed and pale yellow-tan in colour. $90 \%$ are unilateral (arising in one ovary, the other is unaffected). The tumours can vary in size from less than 1 centimetre $(0.39$ in) to 30 centimetres (12 in). Borderline and malignant Brenner tumours are possible but each is rare.

Tumor markers of the malignant neoplasms though useful to monitor the therapy and detect recurrences but because of the rarity and variable histological criteria, there is no established tumor marker for malignant Brenner tumors. Brenner tumors of the ovary usually have no hormonal activities, although there are reports of steroid hormoneproducing Brenner tumors. ${ }^{12,13}$ Biochemical and immunohistochemical studies on estrogen and progesterone receptors in ovarian cancer correlated with the clinical outcome have given varying results. ${ }^{14,15}$ The CA 125 antigen was $06.40 \mathrm{U} / \mathrm{ml}$ in this case (normal $<35.0 \mathrm{U} / \mathrm{ml})$.

Imaging characteristics of benign Brenner tumors are generally resembles other solid ovarian masses such as fibroma, fibrothecoma, and pedunculated leiomyoma. ${ }^{9}$ Sonography, although helpful in differentiating solid from cystic masses, is of more limited utility in detecting small tumors. Athey and Siegel identified 3 of 4 tumors prospectively on sonography; Moon et al reported that 5 $(63 \%)$ of 8 patients had either a predominantly solid or at least a partly solid appearance on CT.9,16 Magnetic resonance imaging may show a $\mathrm{T} 1$ - and T2-weighted hypointense solid component containing fibrous tissue, mimicking a fibroma. ${ }^{17}$

By definition, transitional cell carcinoma of the ovary and malignant Brenner tumors are composed of epithelial cells morphologically resembling urothelium. At matched stage, transitional cell carcinoma of the ovary has a worse prognosis compared to malignant Brenner tumor, therefore, transitional cell carcinoma of ovary should be differentiated from malignant Brenner tumors. ${ }^{18}$

First case of malignant Brenner tumor was described in 1945 by von Numbers. ${ }^{19}$ The criteria for a malignant Brenner tumor proposed by Hull and Campbell in 1973 are as follows: (i) frankly malignant histological features must be present, (ii) there must be intimate association between the malignant element and a benign Brenner tumor, (iii) mucinous cystadenomas should preferably be absent or must be well separated from both the benign and the malignant Brenner tumor and (iv) stromal invasion by epithelial elements of the malignant Brenner tumor must be demonstrated. ${ }^{20}$

Most Brenner tumors are candidates for surgical resection. Malignant Brenner tumors may affect surrounding tissue and metastasize into other structures, but this is so rare that a standard treatment has not been developed. Even malignant Brenner tumors, if diagnosed early, are candidates for complete surgical resection. ${ }^{21}$

\section{CONCLUSION}

Ovarian tumors are fairly common neoplasms. However, the incidence of Brenner tumors is very rare (1.4-2.5\%) of which only $2-5 \%$ is malignant. Histopathological examination remains the gold standard for diagnosis of this entity.

\section{Funding: No funding sources \\ Conflict of interest: None declared \\ Ethical approval: Not required}

\section{REFERENCES}

1. Benson RC. Diagnosis and treatment. Current Obstet Gynaecol. 1976;1:236.

2. Sen U, Sankaranarayanan R, Mandal S, Romana AV, Parkin DM, Siddique M. Cancer patterns in Eastern India: the first report of Kolkata cancer registry. Int J Cancer. 2002;100:86-91.

3. Tortulero L, Mitchell FM, Rhodes HE. Epidemidology and screening of ovarian cancer. Obstet Gynaecol Clin North Amer. 1994;21:63-75.

4. Rashid S, Sarwas G, Ali A. A Clinicopathological study of ovarian cancer. Mother Child. 1998;36:11725.

5. Hemalatha AL, Konanahalli P. Bilateral malignant Brenner tumor of ovary. J Obstet Gynecol India. 2005;55:81-2.

6. Ceausu M, Terzea D, Georgescu A, Dobrea C, Mihai $\mathrm{M}$, Iosif C, et al. Transitional cell tumors of the ovary: a compact group with a heterogeneoushistological and immunophenotypical pattern. Rom J Morphol Embryol. 2008;49:513-6.

7. Vranes HS, Klaric P, Benkovik LB, Pirkic A. Brenner tumor of the ovary. Acta Clin Croat. 2005;44:271-3.

8. Marwah N, Mathur SK, Marwah S, Singh S, Karwasra RK, Arora B. Malignant Brenner tumoura case report". Indian J Pathol Microbiol. 2005;48(2): 251-2.

9. Athey PA, Siegel MF. Sonographic features of Brenner tumor of the ovary. J Ultrasound Med. 1987;6(7):367-72.

10. Green GE, Mortele KJ, Glickman JN, Benson CB. Brenner tumors of the ovary: sonographic and computed tomographic imaging features. J Ultrasound Med. 2006;25(10):1245-51.

11. Caccamo D, Socias M, Truchet C. Malignant Brenner tumor of the testis and epididymis. Arch Pathol Lab Med. 1991;115(5):524-7.

12. Joh K, Aizawa S, Ohkawa K, Dohzono H, Aida S, Ohgoshi E. Case report of a malignant Brenner tumor with hyperestrogenism. Pathol Int. 1995;45:75-84.

13. de Lima GR, de Lima OA, Baracat EC, Vasserman J, Burnier M. Virilizing Brenner tumor of the ovary: case report. Obstet GynecoI. 1989;73:895-8.

14. Rose PG, Reale FR, Longcope C, Hunter RE. Prognostic significance of estrogen and progesterone 
receptors in epithelial ovarian cancer. Obstet Gynecol. 1990;76:258-63.

15. Harding M, Cowan S, Hole D, Cassidy L, Kitchener $\mathrm{H}$, Davis $\mathrm{J}$, et al. Estrogen and progesterone receptors in ovarian cancer. Cancer. 1990;65:486-91.

16. Moon WJ, Koh BH, Kim SK. Brenner tumor of the ovary: CT and MR findings. J Comput Assist Tomogr. 2000;24:72-6.

17. Takahama J, Ascher SM, Hirohashi S, Takewa M, Ito $\mathrm{T}$, Iwasaki S. Borderline Brenner tumor of the ovary: MRI findings. Abdom Imaging. 2004;29:52830.

18. Eichhorn JH, Young RH. Transitional cell carcinoma of the ovary: A morphologic study of 100 cases with emphasis on differential diagnosis. Am J Surg Pathol. 2004;28:453-63.
19. Von Numbers CA. A contribution to case knowledge and histology of Brenner tumor, do malignant forms of the Brenner tumor also occur? Acta Obstet Gynecol Scand. 1945;2 Suppl:114-27.

20. Hull MG, Campbell GR. The malignant Brenner tumor. Obstet Gynecol. 1973;42:527-34.

21. Borah T, Mahanta RK, Bora BD, Saikia S. Brenner tumor of ovary: An incidental finding. J Midlife Health. 2011;2:40-1.

Cite this article as: Jodha BS, Garg R. Brenner tumor of ovary: an incidental finding: a case report. Int J Reprod Contracept Obstet Gynecol 2017;6: 1132-5. 